Jacek Matuszewski

\title{
WPŁYW PRAWA NA CZAS I CZASU NA PRAWO
}

\section{Czas i jego rozumienie}

Żeby czas mógł wpływać na prawo, najpierw prawo musi ustanowić czas. Problem leży jednak w tym, że czasu nie udało się zdefiniować, choć jego definicji odnoszących się do różnorodnych desygnatów jest wiele. Inaczej wygląda czas Newtona, inaczej czas Einsteina. Czym innym jest czas atomowy, gwiazdowy, lokalny, reakcji, rozpadu, pracy, strefowy, uniksowy (czas POSIX ${ }^{1}$ ), uniwersalny, zegarowy i wiele innych. Dla przedstawianych rozważań przyjmiemy upraszczające, a w rozważaniach historycznych w pełni akceptowalne założenie, że interesują nas wzajemne następstwa rozmaitych czynności i wydarzeń, a także metody wymierzania tych relacji oraz związane z nimi, przewidywane przez prawo, konsekwencje ${ }^{2}$.

Człowiek od zarania s dziejów stykał się z czasem³. Początkowo nieświadomie i biernie, z biegiem czasu coraz lepiej i systematycznie zaczął pojmować chronologiczne zależności między różnorodnymi wydarzeniami, by w końcu podjąć próby samodzielnego organizowania i porządkowania swoich relacji z czasem. Przełom w relacji człowieka z czasem nastąpił - jak można przyjąć - wraz z nabyciem umiejętności polowania w grupie. Dotąd każda chwila mogła być przez indywiduum przeznaczona na wszystko, a o sposobie jej wykorzystania przede wszystkim

1 Czas uniksowy, czas POSIX, (ang. Unix time, POSIX time) - system reprezentacji czasu mierzący zegarową liczbę sekund od 1 stycznia 1970, godz. 00:00:00 czasu UTC, czyli od chwili zwanej początkiem epoki Uniksa (ang. Unix Epoch). Kończy się we wtorek, 19 stycznia $2038 \mathrm{r}$.

2 Ograniczenie dotyczy także skali naszych zainteresowań. Pomijamy zupełnie problemy zegarów radioaktywnych czy molekularnych, czyli obliczanie czasu dla wielkości tysięcy milionów lat związane np. z zagadnieniami ewolucji, por. tu R. Dawkins, Najwspanialsze widowisko świata. Świadectwa ewolucji, Stare Groszki 2010, s. 117 i n.; zob. też zestawienie sposobów datowania Tablice historyczne, Warszawa 1996, s. 362; tamże podstawowe informacje o kalendarzach różnych epok, s. 363. Na uboczu pozostawiamy także filozoficzne aspekty wpływu czasu na prawo, por. R. Sobański, „Pro temporis necessitate novas leges condere”. Konieczność czasu jako kategoria prawna we wczesnym średniowieczu, (w:) O prawie i jego dziejach księgi dwie. Studia ofiarowane Profesorowi Adamowi Lityńskiemu w czterdziestopięciolecie pracy naukowej i siedemdziesięciolecie urodzin, Księga I, Białystok-Katowice 2010, s. 199-206.

3 Socjalne aspekty relacji między człowiekiem a czasem analizowano wielokrotnie, por. np. T. Banaszczyk, Czas jako kategoria społeczna, Wrocław 1981; F. Zawielski, Czas i jego pomiary, Warszawa 1981. 
decydował przypadek: pojawienie się pożywienia, wroga, konkurenta, kobiety czy deszczu. Przy uspołecznionym pozyskiwaniu pożywienia - przez grupę, czas zaczął wymagać organizacji, a w konsekwencji pojawiała się zarówno możliwość, jak i konieczność porządkowania także nowego zjawiska - społecznego „czasu wolnego", po polowaniu i uczcie (wyrób narzędzi, bezpieczny wypoczynek, prokreacja, kultura i religia, np. ceremonie pogrzebowe czy strojenie się). Przygoda człowieka z czasem zaczynała się zatem od całkowitego niemal podporządkowanie się, ale prowadziła do coraz skuteczniejszych prób uniezależnienia się od niego. Regulacje prawne, służące uporządkowaniu zasad funkcjonowania czasu w prawie, odnosiły się i odnoszą do dwóch sfer: kalendarza i zegara. I na tej dopiero podstawie możliwa była budowa wszystkich dalszych relacji między czasem a prawem.

\section{Prawo czasu}

\subsection{Kalendarz ${ }^{4}$}

Coraz bardziej skomplikowana cywilizacja społeczności ludzkiej prowadziła do podporządkowywania natury człowiekowi, także w odniesieniu do czasu. Właściwe uporządkowanie tego czasu, umiejętność zarządzania nim, stanowiło warunek sukcesu grupy. A poprawność uporządkowania zależała od umiejętności przewidywania przyszłości ${ }^{5}$. Z kolei ta umiejętność mogła być doskonalona dzięki znajomości przeszłości ${ }^{6}$. Rzutowaniu powtarzalnych elementów przeszłości w przyszłość służy kalendarz. Kalendarz to metoda oznaczania dni, przez przypisanie ich latom, miesiacom i ewentualnie tygodniom ${ }^{7}$. Najstarsze kalendarze (sprzed 17-13 tys. lat) rejestrowały poznane przez człowieka prawa przyrody: wędrówki zwierząt, pory roku, fazy księżyca ${ }^{8}$. Miały zatem charakter narzędzia człowieka podporządkowanego, ale coraz bardziej świadomego natury. Kolejnym krokiem było samodzielne stworzenie już abstrakcyjnego kalendarza, który miał służyć obok funkcji praktycznych poprawnemu realizowaniu zadań związanych z kontaktem z siłami nadprzyrodzonymi. W taki sposób pojawiły się funkcjonujące do dziś i dominujące w systemach porządkowania czasu kalendarze religijne. I dopiero one umożliwiły oddziaływanie czasu na prawo. Prawem określony sposób obliczania (ustalania) czasu był warun-

\footnotetext{
$4 \quad$ Kalendarz to narzędzie organizacji czasu, najczęściej w skali jednego roku. Warto zwrócić uwagę na koncepcje zakładające odmienne wartości społeczeństwa posługującego się kalendarzem od tych - postępowych - społeczności terminarza, por. E. Trawkowska, Czas w życiu Polaków. Wyniki badań. Hipotezy. Impresje, Warszawa 1992.

5 J. Szymański, Nauki pomocnicze historii, Warszawa 1983, s. 117-120.

$6 \quad$ Wskażmy przykładowo określanie czasu za pomocą odwoływania do faktów i wydarzeń powszechnie, przynajmniej w skali lokalnej, znanych. Obok odwołania do narodzin Chrystusa, spotykamy i inne: tedy, gdy ze mna (...) w karczmie siedział i piwo pił. Cały szereg innych zwrotów temporalnych o znaczeniu prawnym zestawia G. Myśliwski, Człowiek średniowiecza wobec czasu i przestrzeni, Warszawa 1999, s. 339-349.

$7 \quad$ E.G. Richards, Kalendarz i jego historia. Odmierzanie czasu, Warszawa 1999, s. 13.

8 Zob. J. Burke, R. Ornstein, Ostrze geniuszu. Obosieczne skutki rozwoju cywilizacji, Warszawa 1999, s. 41-43.
} 
kiem podporządkowania i uzależnienia prawa od rozmaicie określanych (zgodnie z prawem) i ustalanych terminów.

W dziejach kalendarza wyróżnić należy dwie epoki - czasy kultury oralnej, gdy brak możliwości konstruowania stabilnego punktu odniesienia prowadzi do cyklicznego systemu organizacji czasu i epokę kultury pisma, pozwalającej stworzyć linearny system rachuby czasu, w którym stały, choć fikcyjny (legendarny) punkt odniesienia (stworzenie świata, założenie Miasta, narodziny Chrystusa) narzuca continuum wszystkich wydarzeń 9 . Pismo, a wraz z nim kalendarz, stanowiły efekt narastającego zapotrzebowania rozwijającej się gospodarki (terminy kontraktów), biurokracji (ściąganie podatków) i religii (skuteczny rytuał tylko w tradycyjnych dniach ${ }^{10}$ ). O ile bowiem rolnictwo, myślistwo, zbieractwo czy zbójeckie napady na bliższych czy nieco dalszych sąsiadów mogły być sprawnie realizowane przy wykorzystaniu jedynie kalendarza natury, to rozwój miast i handlu, a co za tym idzie - finansów publicznych, kredytu, imperialnych działań militarnych, nie mógł być realizowany bez znajomości sztucznego (abstrakcyjnego) kalendarza. Przy jego konstrukcji wykorzystywano wiedzę, pozwalającą mierzyć w sposób jednolity czas ruchów łatwych do powszechnej obserwacji, ubóstwionych ciał niebieskich (słońca, księżyca, planet czy gwiazd). Zrozumiałe też, że charakter religijny kalendarza prowadził do powierzenia kaście kapłańskiej nadzoru nad jego funkcjonowaniem. Ale decyzje o obowiązującym charakterze tego czy innego kalendarza podejmowała i podejmuje władza świecka ${ }^{11}$.

Przedstawmy dla przykładu procedury związane z nadaniem mocy obowiązującej przez narzucony całemu niemal światu w ciagu europejskiej ekspansji XIX w. system kalendarza gregoriańskiego. Ma on u swojej podstawy pogański kalendarz wprowadzony w 46 r. p.n.e. przez Juliusza Cezara. Początkowo wskazywał on lata ab Urbe condita (753 r. p.n.e.), by od 532 r. n.e. (Dionizy Mały) powoli przyjmować jako punkt odniesienia domniemaną datę narodzin Chrystusa. Kalendarz ten miał dla Kościoła ogromne znaczenie ${ }^{12}$, ale narastająca rozbieżność miedzy rokiem kalendarzowym a astronomicznym rodziła konieczność naprawy ${ }^{13}$, którą po ponad

Może to być koncepcja postępu, ale także regresu: gdy np. wiek brązowy poprzedzany jest przez najpierw wiek złoty, a potem srebrny lub podobnie, gdy po pobycie w raju następuje ziemska tułaczka; zob. J. Goody, Kradzież historii, Warszawa 2009, s. 24-29.

10 Tego rodzaju prymitywny efekt funkcjonuje jeszcze w czasach nowożytnych, gdy w związku z wprowadzeniem reformy gregoriańskiej dni poświęcone świętym ulegały przesunięciu, to rodziły się niepokoje wśród wiernych, wywołane wątpliwościami, czy święty będzie wiedział, że teraz ma wysłuchiwać modłów w dniu określonym wg kalendarza nie juliańskiego, lecz 10 dni wcześniej, wg kalendarza gregoriańskiego.

Wskażmy przykładowo: Solon w Atenach (VI w. p.n.e.), Juliusz Cezar wprowadzający reformę, tzw. kalendarz juliański, Napoleon znoszący tzw. kalendarz rewolucyjny, władze Związku Radzieckiego zastępujące kalendarzem gregoriańskim, kalendarz juliański (1918 r.), a następnie wprowadzające nowy kalendarz, z nowym tygodniem (1930 r.) i znoszące rewolucyjną reformę (1940 r.).

12 Na jego podstawie corocznie budowano nowy kalendarz liturgiczny.

13 Wagę, jaką przywiązywano do poprawności kalendarza ilustruje wypowiedź jednego z kardynałów na soborze w Konstancji (1415 r.), że obliczenia kalendarzowe są dla wiary ważniejsze niż obliczenia finansowe, (E.G. Richards, Kalendarz i jego historia. Odmierzanie czasu, s. 218), co zrozumiałe, skoro taki był w owych dniach za- 
350 lat trwających pracach zrealizowała 24 lutego 1582 r. ${ }^{14}$ bulla Grzegorza XIII Inter gravissimas. Opublikowana 1 marca na drzwiach bazyliki św. Piotra została równocześnie rozesłana do władców państw katolickich. Przyjmowano ją w sposób rozmaity. W Hiszpanii moc świecką (obowiązek posługiwania się gregoriańską datacją dotyczył zawieranych kontraktów, urzędowych aktów i wyroków sądowych, korespondencji itd.) nowy kalendarz uzyskał dekretem Filipa II z 19 września 1582 r., a korektę bieżącej daty przeprowadzono zgodnie z papieską decyzją przez przejście po dniu 4 października od razu do 15 października. W Anglii zainteresowana wprowadzeniem reformy królowa Elżbieta musiała zrezygnować z jej realizacji m. in. wobec sprzeciwu duchownych protestanckich, niechętnych jakimkolwiek formom papieskiej władzy i dopiero w $1751 \mathrm{r}$. parlament przyjął ustawę ustanawiającą nową rachubę czasu ${ }^{15}$. Najbardziej nieodpowiedzialnie reformę wprowadzano w innym protestanckim kraju, Szwecji. W obawie przed niepokojami społecznymi ${ }^{16}$ postanowiono, by od 1700 r. co 4 lata rezygnować tylko z jednego dnia przestępnego, co miało po 40 latach doprowadzić do zgodności z kalendarzem gregoriańskim. Usunięcie dnia przez administracyjne niedopatrzenie miało miejsce tylko raz. W efekcie Szwecja nie miała już kalendarza juliańskiego, ale nie zdołała też wprowadzić kalendarza gregoriańskiego. Wobec nieudolnie przeprowadzanej reformy w $1712 \mathrm{r}$. przywrócono kalendarz juliański, a dla uzyskania zgodności luty tego roku miał w Szwecji 30 (!) dni ${ }^{17}$. I dopiero w 1753 r. uznano kalendarz gregoriański (po 17 lu-

męt, że Wielkanoc zdarzyła się dwa razy tego samego roku (D.E. Duncan, Historia kalendarza. Jak człowiek nauczył się określać rok, Warszawa 2002, s. 113).

14 Bulla datowana jest: 1581 r., gdyż w chwili jej wydania nowy rok (a więc 1582) zaczynał się nie 1 stycznia, lecz dopiero 25 marca.

15 Likwidacji na terenie imperium uległy dni od 3 do 13 września 1752 r.: and that the natural Day next immediately following the said Second Day of September, shall be called, reckoned and accounted to be the Fourteenth Day of September, omitting for that Time only the eleven intermediate nominal Days of the common Calendar; Dodatkowo przeniesiono początek roku z 25 marca na 1 stycznia: and that the first Day of January next following the said last Day of December shall be reckoned, taken, deemed and accounted to be the first Day of the Year of our Lord One Thousand Seven Hundred and Fifty-Two (Chesterfield Act).

16 Wprowadzenie nowego kalendarza wiązało się $z$ „utrata” 10 dni. Było to źródłem zamieszek wywoływanych niezadowoleniem „z kradzieży” tego czasu. Abp Iwowski próbował przy pomocy wojska wymusić respektowanie nowego kalendarza na Rusi. Z tego właśnie powodu m.in. Batory zgodził się na odłożenie wprowadzenia nowego kalendarza w Inflantach, ale równocześnie bezwzględnie żądał stosowania kalendarza w protestanckim Gdańsku. Niekiedy prawodawca popełniał niezręczność, jak np. w Belgii, gdzie po 21 grudnia 1582 r. następował 1 stycznia 1583 r., co pozbawiło tego roku ludność świąt Bożego Narodzenia, podobnie w Transylwanii, gdzie zlikwidowano dni od 15 do 24 grudnia 1590 r. Natomiast protestanckie kantony Szwajcarii pozbawiły w roku 1700 swych mieszkańców dnia Nowego Roku, likwidując dni między 31 grudnia 1700 r. a 12 stycznia 1701 r.

17 Luty dwukrotnie miał 30 dni w Związu Radzieckim (1930 r. i 1931 r.). Zauważmy też, że Szwecja nie była jedynym krajem, w którym powrócono do stylu juliańskiego. Takie zjawisko obserwujemy na terenach byłej Rzeczypospolitej włączanych do Rosji. Obszar I zaboru powrócił do kalendarza juliańskiego w 1782, Kurlandia 1796, a na pozostałym terytorium miało to miejsce w roku 1800. Podwójną datację na terytorium Królestwa Polskiego wprowadziło postanowienie Rady Administracyjnej z 4/16 stycznia 1835 r., choć w praktyce datację podwójną (Stary Styl obok Nowego Stylu) stosowano już od chwili utworzenia Królestwa przy publikacji w Dzienniku Praw Królestwa Polskiego aktów wydawanych przez cara w Petersburgu (zob. też niżej przyp. 24). W 1923 r. na prawosławnej konferencji w Konstantynopolu uzgodniono reformę kalendarza juliańskiego, ale nie przyjęto jej powszechnie. W efekcie dziś funkcjonują co najmniej dwa kalendarze juliańskie: oryginalny (wykorzystywany w kościołach tzw. starokalendarzowców) i zrewidowany (neojuliański). 
tego nastąpił 1 marca). Wprowadzanie stanowiącego dziś światowy standard kalen-

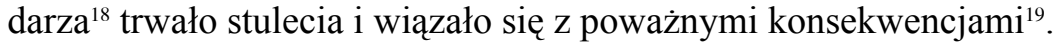

Zmiana kalendarza rodziła problemy wynikające $\mathrm{z}$ konieczności posługiwania się różnymi technikami określania dat dla tych samych stosunków. $Z$ jednej strony może to prowadzić do konieczności uwzględniania w obrocie podwójnej datacji: np. w Królestwie Polskim obowiązywała reguła równoczesnego wskazywania daty wg Starego Stylu (kalendarz juliański) i Nowego Stylu (wg kalendarza gregoriańskiego). Dodatkową trudność stwarzały odmienności w dacie zaczynającej kolejny rok. Od średniowiecza najczęściej konkurowały ze sobą trzy terminy początkujące nowy rok: Boże Narodzenie (25 grudnia), Circumcisio Domini (1 stycznia) i 25 marca $^{20}$. Dzięki temu do dziś istnieje możliwość wskazania, że ścięcie Karola Stuarta miało miejsce albo w roku 1648 albo 1649. Niełatwo nawet rozstrzygnąć, czy wprowadzająca reformę kalendarza bulla Grzegorza XIII wydana została w 1571 czy 1572 r.

Już bulla z 1582 r. zawierała rozstrzygnięcia dotyczące stosunków prawnych kształtowanych z uwzględnieniem czasu: Ne vero ex hac nostra decem dierum subtractione, alicui, quod ad annuas vel menstruas prestationes pertinet, preiudicium fiat, partes iudicum erunt in controversis, que super hoc exorte fuerint, dicte subtractionis rationem habere, addendo alios $X$ dies in fine cuiuslibet prestationis. Nakazano zatem, by zniesienie 10 dni w roku 1582 nie prowadziło do strat osób, które zawarły terminowe kontrakty. Równocześnie rozstrzygano o wyłącznym charakterze nowego sposobu obliczania czasu: and that all Acts, Deeds, Writings, Notes and other Instruments of what Nature or Kind soever, whether Ecclesiastical or Civil, Publick or Private, which shall be made, executed or signed, upon or after the said first Day of January One Thousand Seven Hundred and Fifty-Two, shall bear Date according to the said new Method of Supputation - nakazal akt Jerzego. Jeszcze inaczej postapiła niemiecka władza okupacyjna, podejmując w 1915 r. decyzję o zmianie kalendarza. 21 marca Naczelny Wódz na Wschodzie von Hindenburg wydał Rozporzqdzenie dotyczqce zaprowadzenia kalendarza Gregoryańskiego i czasu średnioeuropejskiego (niemieckiego), jak też zniesienia tzw. galówek dla obszarów Polski rosyjskiej, podlegajacej niemieckiej administracji. Od dnia 1 kwietnia na terenie okupowanym, zgodnie z § 1 Rozporządzenia: Czas kalendarzowy oblicza sie podtug kalendarza Gregoryańskiego (nowego stylu) ${ }^{21}$. I tyle. Konsekwencje tak lakonicznego rozstrzygnięcia nie były dla ludności nadzwyczaj dotkliwe zapewne

18 Dziś nie ma on charakteru oficjalnego m.in. w Afganistanie i Iranie, gdzie obowiązuje kalendarz perski, a także w Izraelu, gdzie jako oficjalny występuje kalendarz żydowski. O równoległym funkcjonowaniu dwóch lub więcej kalendarzy zob. J. Szymański, op. cit., s. 128-129.

19 Por. przykładowe zestawienie dat przyjęcia nowej chronologii w Europie, m.in. J. Szymański, op. cit., s. 128 oraz tabela s. 735 .

20 Zob. Chronologia Polska, red. B. Włodarski, Warszawa 1957, s. 57-70.

$21 \S 2$ przewidywał wprowadzenie czasu niemieckiego: Porę dzienną liczy się podług czasu średnioeuropejskiego (niemieckiego). Miesiąc później (23 kwietnia) identyczne rozstrzygnięcie przyjęte zostało na terenie okupacji austriackiej, zob. J. Lewandowski, Królestwo Polskie pod okupacją austriacką 1914-1918, Warszawa 1980, s. 33. 
dzięki temu, że decyzja zmieniała stan faktyczny, w którym obowiązywała podwójna datacja: Stary Styl/Nowy Styl22.

Wskazanie przez prawodawcę systemu obowiązującego kalendarza nie rozwiązuje wszystkich problemów związanych z wpływem czasu na prawo. Poszczególne jednostki np. kalendarza gregoriańskiego nie są do siebie w pełni dopasowane: ani rok nie zawiera w sobie równej liczby miesięcy, ani miesiąc nie obejmuje pełnej liczby tygodni ${ }^{23}$. Do tego miesiąc miesiącowi nierówny, a i rok bywa różnej długości. Prawo wymaga jednak precyzji i dlatego nie należy dziwić się, że zmierza do usunięcia wszelkich wątpliwości. Stąd wciąż podejmowane są próby przeprowadzenia kolejnych reform kalendarza ${ }^{24} \mathrm{z}$ jednej strony. $\mathrm{Z}$ drugiej możemy przywołać praktykę ustawodawczą zmierzającą do racjonalizowania i unifikacji konsekwencji wynikających z założeń pogańskiego kalendarza ustalonego przed 2000 laty. Jako konsekwentny przykład można wskazać Kodeks prawa kanonicznego z 1917 r. ${ }^{25}$, w którym rozstrzygnięto, co do zasady - i powtórzono w nieco zmienionej formie w roku 1983 - że dzień zaczyna się od północy, doba liczy sobie 24 godziny, tydzień $7 \mathrm{dni}$, miesiąc $30 \mathrm{dni}$, a rok 365. Jednak nie zawsze prawodawca pamięta o takich rozstrzygnięciach, w konsekwencji czego możliwe są sytuacje, że 3 miesiące oznaczać mogą w świetle prawa okres czasu liczący od 89 do 92 dni² ${ }^{26}$.

\subsection{Zegar}

Zegar, w przeciwieństwie do kalendarza, jest przyrządem do ciagłego cyklicznego pomiaru czasu w ramach dnia lub doby. Dotyczy jednak małej jednostki, która

22 Datowanie aktów za pomoca dwóch stylów równocześnie zrodziło się w praktyce Królestwa Polskiego. Początkowo tak datowano akty wystawiane w Petersburgu (zob. Dziennik Praw Królestwa Polskiego), stosując tylko Nowy Styl w aktach lokalnych Królestwa. Od 1835 r. zaczyna upowszechniać się obowiązek podwójnej datacji także aktów powstających i pozostających w Królestwie (np. aktów notarialnych). Wprowadzenie w stosunkach publicznych wyłącznie kalendarza juliańskiego nastapiło po powstaniu styczniowym ukazem z 23 marca 1871 r., ustalając dla terenu Królestwa rosyjski system promulgacji aktów prawnych.

23 Pozostawiamy na uboczu kwestie narzucenia przez władzą publiczną tygodnia religijnego (cesarz Konstantyn Wielki wprowadza tydzień siedmiodniowy poczynający się od niedzieli 321 r., czy zastapienie tygodnia siedmiodniowego dziesięciodniowym - dekret Zgromadzenia Narodowego z 24 listopada 1793 r.) lub rezygnacji zeń; zob. też J. Matuszewski, Słowiański tydzień: geneza, struktura, nomenklatura, Łódź 1978.

24 Zob. np. charakterystykę propozycji nowego światowego kalendarza: The proposed scheme of the World Calendar has overcome all the above drawbacks of the present Gregorian Calendar. It is scientific, uniform, stable and perpetual with but one unvarying calendar every year. It retains the present 12 months; thus the four quarters are always equal; each quarter has 3 months, 13 weeks, or 91 days, beginning on Sunday and ending on Saturday; each month contains an exact number of 26 working days plus Sundays; and days and dates always agree from year to year, and holidays are permanently fixed. The calendar remains identical from year to year. It offers harmony and order to all strata of society - government, finance, industry, labour, retail trade, administration of justi$\mathrm{ce}$, homelife, transportation and education. All statistics compiled on the basis of a month, a quarter or a year are strictly comparable with one another. E/2514 z 30 października 1953 r.: Communication dated 28 October from the Permanent Representative of India to the United Nations to the Secretary-General.

25 Codex iuris canonici, Romae 1927, Can. 31-35. Zauważmy, że przyjęcie takiego kalendarza na zawsze zlikwiduje lub utrwali tzw. wydłużone weekendy.

26 Tak kodeks postępowania karnego z 1997 r., por. tu Postanowienie z dnia 20 maja 2008 r. Sądu Apelacyjnego w Krakowie, II AKZ 236/08. To interesujące zagadnienie z przyczyn technicznych sygnalizujemy jedynie, choć nasuwać się może problem zgodności z konstytucyjną zasadą równości niejednolita długość (z przyczyn kalendarzowych) takiego samego wymiaru kary. 
w stosunkach wiejskich długo nie odgrywała większego znaczenia. Dopiero wzrost roli miast i oderwanie człowieka od podporządkowania cyklowi przyrody prowadzi do konieczności uporządkowania czasu w sposób niezależny od pory roku. Dodatkową trudność stwarzał fakt, że podstawowe części naturalnej jednostki czasu, obsługiwanej przez zegar - doby, składają się z dzielonych na godziny dni i nocy. Liczba godzin jest stała, ale długość dnia i nocy podlega permanentnej, wzajemnie uwarunkowanej zmianie. W konsekwencji czas trwania godzin też musiał się zmieniać: godziny nocy skracały się latem, a wydłużały zimą, zaś godziny dnia odwrotnie, trwały dłużej latem, a krócej zimą, co w pełni odpowiadało technologii pracy na roli, ale wykluczało możliwość racjonalnego posługiwania się zegarem²7. Jego użyteczność w całej pełni ujawniła się dopiero w społeczeństwie miejskim ${ }^{28}$.

\section{Czas prawa}

Przedstawiliśmy wyżej podstawowe elementy kształtowania czasu przez prawo. Przynajmniej równie ciekawym zagadnieniem jest relacja przeciwna, czyli sposób oddziaływania czasu na prawo. W tym zakresie możemy także zasygnalizować tylko niektóre zagadnienia, ograniczając się do rozważenia kwestii czasu obowiązywania prawa (w tym zasady lex retro non agit) oraz wpływu czasu na utratę prawa (dawność/przedawnienie) ${ }^{29}$.

Początkowo funkcjonował wyłącznie system prawa zwyczajowego, w którym problem początku i końca mocy obowiązującej normy w ogóle nie występował. Prawo zwyczajowe nie obowiązywało na mocy woli prawodawcy - twórcy prawa w dzisiejszym rozumieniu w ogóle nie było. Prawem były bowiem reguły uznawane powszechnie za słuszne, dobre, skuteczne, ustanowione przez mitycznych przodków (starców) lub wynikające z odwiecznej woli siły nadprzyrodzonej. A w stosunku do takich pytania co do czasu obowiązywania w ogóle nie można stawiać. Sytuacja uległa zmianie z chwilą pojawienia się prawa stanowionego. Wówczas należało określić chwilę wejścia w życie nowego ${ }^{30}$. Zwyczajowo nowe prawo zaczynało obowiązywać dopiero po ogłoszeniu, choć niekiedy prawodawca precyzyjnie wskazywał datę, nakazując, by np. starostowie publikowali prawo w dni świąteczne

27 Por. M. Kopczyński, Ludzie i technika, rozdz. 1: Nieznani mnisi: od klepsydry do zegarka kwarcowego, Warszawa, s. 17-29.

28 Prawne regulacje czasu zegarowego pozostawiamy na uboczu. Szerzej o zegarze zob. J. Zajdler, Dzieje zegara, Warszawa 1980.

29 Czas odgrywa znaczącą rolę w prawie publicznym, $m$. in. regulując funkcjonowanie naczelnych organów państwa, wskazując kadencje urzędnicze, terminy zwoływania sejmu, sejmików, czas ich trwania, problem limity, terminy roków sądowych, określa organizację poboru świadczeń publicznych, por. tu np. G. Myśliwski, Człowiek średniowiecza wobec czasu i przestrzeni (Mazowsze od XII do poł. XVI wieku), Warszawa 1999, s. 197-433. początkowo nie pojawiała się potrzeba rozstrzygania o wzajemnej relacji starego i nowego prawa, a w razie konkurencji decydowała praktyka, najczęściej odrzucająca zresztą zmiany wprowadzone przez ustawodawcę. 
i targowe $u$ t moris est, i dodając: premissarum constitutionum executio a festo sancti Stanislai, nunc instante in Maio incipit ${ }^{31}$.

Koniec obowiązywania normy następował przez nadejście terminu wskazanego przez ustawodawcę w akcie prawnym - konstytucje czasowe. Natomiast przepisy wydane bez takiej klauzuli obowiązywały najczęściej aż do ich uchylenia lub zmiany. Jednak abrogacji i derogacji towarzyszyła specyficzna szlachecka desuetudo. I to występująca na ogromną skalę. Słabość władzy wykonawczej państwa szlacheckiego prowadziła po prostu do niewykonywania prawa ${ }^{32}$. Stąd dodatkowe, choć mało skuteczne sposoby nadawania mocy obowiązującej nierespektowanym normom: innowacja, reasumpcja, deklaracja ${ }^{33}$. Zmiana w tym zakresie nastapiła wraz $\mathrm{z}$ upowszechnieniem zwyczaju kodyfikowania prawa. Dopiero wtedy prawodawca został zmuszony do wyraźnego określenia granic czasowych obowiązywania nowego prawa i chwili odebrania mocy prawu dotychczasowemu. I tak przykładowo ustawy przechodnie z okazji wprowadzenia Kodeksu Napoleona w Księstwie Warszawskim zamieszczono na 15 stronach $^{34}$.

Istotną kwestią zakresu czasowego mocy obowiązywania prawa jest jego relacja do wydarzeń i stosunków prawnych zaistniałych przed wejściem w życie nowej regulacji. Problem ten pojawił się dopiero wraz z prawem stanowionym. Nie dziwimy się zatem, że w Statutach Kazimierza Wielkiego (poł. XIV w.) znajdujemy następujące postanowienie: cum omnes constitutiones et statuta legem imponant rebus et negotiis futuris et non preteritis. Stanowi ono w Polsce najstarszy tak jasny zapis zasady nieretroakcji prawa. Jednak nie przesądza on o ostatecznym jej przyjęciu ${ }^{35}$, będącym dopiero wynikiem długotrwałego procesu narastającej dominacji prawa stanowionego nad zwyczajowym ${ }^{36}$. $\mathrm{Z}$ interesującego nas punktu widzenia istotny jest pewien szczególny aspekt nadużycia prawa przez odwoływania się do tej zasady, jako podstawy do ochrony praw nabytych. W licznych aktach prawnych uchwalanych przez szlachecki sejm napotkać można odpowiednią, zapewniającą ochronę praw nabytych, klauzulę: salvis tamen modernis possessoribus ${ }^{37}$. W państwie szlacheckim zjawiskiem powszechnym było nierespektowanie prawa - także przy wy-

31 Corpus luris Polonici, ed. O. Balzer, Kraków 1906, t. II, nr 89 (wykonanie konstytucji ma się rozpocząć od dnia świętego Stanisława najbliższego w maju).

32 Szesnastowieczny szlachecki ruch egzekucyjny nazwę swą wziął od programowego postulatu reformy państwa polegającej na przywróceniu przestrzegania prawa.

Przy okazji mogła mieć miejsce nowelizacja lub interpretacja odnawianych przepisów, por. H. Grajewski, Granice czasowe mocy obowiąującej norm dawnego prawa polskiego, Łódź 1970.

Prawo cywilne obowiązujące w Królestwie Polskiem, wyd. S. Zawadzki, Warszawa 1860. Por. też Rozporządzenie Prezydenta Rzeczypospolitej z dnia 27 czerwca 1934 r., Dz.U. RP 1934 r. nr 57, poz. 503, w którym zawarto na 30 stronach przepisy wprowadzające kodeks handlowy, Kodeks Handlowy i Przepisy Związkowe, zestawił i wstępem zaopatrzył prof. dr J. Górski, Poznań 1948, s. 258-287.

Zob. monografię poświęconą kwestii nieretroakcji prawa w państwie szlacheckim: H. Grajewski, Zasada „lex retro non agit" w praktyce sądów polskich do połowy XVI w., Łódź 1971.

36 I znowu Kodeks Napoleona posłużyć może jako podręcznikowy przykład: Prawo obowiązuje tylko na przyszłość, nie ma mocy wstecznej (art. 2), co w Kodeksie cywilnym Królestwa Polskiego (1825 r.) sformułowano następująco: Prawo stanowi tylko na przyszłość, a nie rozciaga swych skutków na przeszłość (art. 2). 
korzystywaniu swych uprawnień rozdawniczych przez króla. Monarcha rozdawał (nadawał) to, czego rozdawać nie było wolno, nadawał osobom, którym to nie przysługiwało (np. naruszając incompatibilitas). Rozeźlona szlachta wytykała tę praktykę na kolejnych sejmach, podejmując uchwały przypominające (powtarzające) od dawna istniejące zakazy i ograniczenia. Ale wprowadzała do nich klauzule salwatoryjne, zapewniające zachowanie praw nabytych wbrew prawu, ale już nabytych. Stąd klauzule te zasłużyły sobie na miano klauzul niepraworządnościci ${ }^{38}$, stanowiły bowiem nie instrument ochrony prawa, ale chroniły prawa uzyskane w drodze złamania prawa.

Ochrona prawa przed upływającym czasem, a także ochrona stanu faktycznego, przeciwnego prawu, początkowo dotyczyła wyłącznie sfery obejmowanej pamięcią ludzką. Czego nie pamiętano, tego prawo bronić - co oczywiste - nie mogło. Przed pojawieniem się pisma pamięć była jedynym sposobem rejestrowania uprawnień. Nie miało znaczenia liczenie czasu. W wypadku sporu broniący się przed roszczeniem mógł jedynie wykazywać, że kwestionowany stan istnieje tak długo, że innego nikt nie pamięta ${ }^{39}$.

W czasach, gdy uchwalano Statuty Kazimierza Wielkiego, pismo (dokument i księga sądowa) staje się szeroko dostępne. Obok pamięci ludzkiej zaczyna funkcjonować nowy, znacznie doskonalszy mechanizm rejestracji stosunków prawnych, pozwalający odwoływać się do stanów prawnych występujących poza ludzką pamięcią. A to grozi destabilizacją wynikającą z niepewności, czy stan faktyczny jest zgodny z istniejącym przed laty stanem prawnym. Pojawia się więc potrzeba skrupulatnego uzgodnienia stosunków faktycznych ze stanem prawnym. W tym celu wykorzystano czas. Ustawodawca przy pierwszej okazji korzysta z możliwości wprowadzenia w Statutach sankcji dla tych wszystkich, którzy byli leniwi i niedbali: Cum prescriptio propter segniciam et pigriciam dominorum est instituta (art. 38 Król ${ }^{40}$. Odwołując się do czasu dla zmiany stanu prawnego, ${ }^{41}$ podkreślano w tym pomniku kilkukrotnie, że dawność jest karą za niedbalstwo i lenistwo uprawnione$\mathrm{go}^{42}$. Dlatego też przewidziano krótkie terminy z jednej strony. $\mathrm{Z}$ drugiej, przyjęto, że dawność skutecznie niszczy prawo niekorzystającego zeń wówczas jedynie, gdy konkurent, niezależnie od tytułu prawnego i dobrej wiary, z tego prawa przez wskazany przeciag czasu korzysta.

\footnotetext{
38 Zob. H. Grajewski, op. cit., s. 107 i n., gdzie wskazano także (s. 108-109) mechanizmy wykorzystywane do zamieszczenia interesującego nas ograniczenia mocy przepisu.

39 Sięgano do stosowanego w prawie kanonicznym zwrotu: cuius contrarii memoria non existit. Najczęściej uznawano pamięć 3 pokoleń, czyli ok. 100 lat: quia a centum annis de preavo et avo in mea parte tabernam habeo (1388 r.). Zauważmy, że pojęciem tym posługuja się jeszcze twórcy kodeksu Napoleona w art. 691: Posiadanie nawet od niepamiętnych czasów, nie wystarcza do ich [służebności ciagłych niewidocznych] nabycia.

40 Zob. S. Roman, Z badań nad dawnością w prawie polskim XIV wieku, „Czasopismo Prawno-Historyczne” 1965, t. 17, z. 2, s. 71 in.

41 Czas mógł pozbawiać prawa rzeczowego, oddziaływać na roszczenie wierzyciela, szkodzić w procesie, a nawet uniemożliwiać ściganie przestępcy.

42 Zob. P. Dąbkowski, Prawo prywatne polskie, t. I, Lwów 1910, s. 296 i n.
} 
Upowszechnieniu krótkich terminów dawności towarzyszyło ograniczenie jej działania. $Z$ jednej strony przewidywano zawieszenie jej biegu (iuristicium) - kiedy to czas, z punktu widzenia prawa, doraźnie przestawał biec (bezkrólewie, czas zarazy, wojny itd., wszelkie okoliczności utrudniające dostęp do wymiaru sprawiedliwości lub uniemożliwiające wykonywanie prawa - uwięzienie, służba królewska). Z drugiej, kształtowała się sfera stosunków prawnych wyjętych w ogóle spod działania czasu. Szczególną ochroną przed skutkami upływu czasu objęte były, i to od czasów Justyniana, uprawnienia kościoła, w stosunku do których stosowano prescriptio centum annorum ${ }^{43}$.

W tym zakresie szczególnie interesująco kształtowała się ochrona praw monarchy (później państwa - fiscusa). Zasada nullum tempus currit contra regem, podobnie jak wobec praw kościoła, wyrosła ze 100 lat liczącego terminu preskrypcji. Przywileje kościoła na świeckie państwo przeniósł Fryderyk II, w odniesieniu do przedawnienia, stwierdzając expressis verbis: Wydtużamy prawo zasiedzenia z okresu czterdziestu i sześćdziesięciu lat, które dotychczas obowiazywało w sprawach publicznych przeciwko skarbowi, do okresu stu la $t^{44}$.

Wyprowadzanie uprawnień państwa z przywilejów kościoła znajdowało głębokie uzasadnienie w kształtującej się w średniowieczu - zwłaszcza w angielskiej myśli politycznej - paraleli Christus - Fiscus i postępującym za tym związaniem koncepcji res sacrae kościoła i res quasi sacrae władcy. Czas został tu wykorzystany przy kreowaniu odrębności państwa od piastującego urząd głowy państwa monarchy. Ten ostatni bowiem w odniesieniu do czasu występował w dwóch postaciach, gdyż z jednej strony, w sprawach doczesnych, prywatnych, podporządkowany był czasowi, z drugiej, w sprawach dotyczących wszystkich (publicznych) - stał ponad czasem $^{45}$. W tym drugim przypadku eksponować trzeba też konsekwencje w postaci uchylenia dawności w relacjach publicznych, mocno związanych z równocześnie kształtującą się zasadą niezbywalności (l'inaliénabilité du domaine) i nienaruszalności domeny królewskiej, a później domeny koronnej.

Zasada wyłączenia uprawnień monarszych spod wpływu dawności ukształtowała się także w Polsce - przeciwko królowi dawność nie biegła w ogóle, ale równocześnie władca w sporze z poddanym mógł z dobrodziejstw dawności korzystać ${ }^{46}$. Tak uprzywilejowane stanowisko skarbu w czasach nowożytnych zostało poważnie ograniczone przez powrót do zasady, że upływ czas może skutecznie wpływać na utratę uprawnień przez władzę publiczną.

Tak długi termin preskrypcji prowadził ostatecznie do generalnego jej odrzucenia: videtur certe impossibile probari prescriptionem centum annorum.

E.H. Kantorowicz, Dwa ciała króla, Studium ze średniowiecznej teologii politycznej, Warszawa 2007, s. 148.

Por. rozróżnienie między dwoistością władcy: królem feudalnym a królem fiskalnym, E.H. Kantorowicz, op. cit., s. 140.

P. Dabbkowski, op. cit., s. 185; L. Sobolewski, W. Uruszczak, Artykuły mielnickie z roku 1501, „Czasopismo Prawno-Historyczne" 1990, t. XLII, z. 1/2, s. 64. 


\title{
THE INTERACTION OF TIME AND LAW
}

\author{
SUMMARY
}

If time is to shape the law, first it has to be recognized by law. This article undertakes the issue of legislating the measurement of time. It shall focus on the granting of a binding force to calendars and to the clock of time itself and, in particular, on imposing global application of the Gregorian Calendar. Then the two following matters shall be considered: the time limits of a binding force of law and how the passage of time affects rights not exercised. 